\title{
Janus-Faced: Post-Revolutionary Slavery In East and West Jersey, 1784-1804
}

Timothy Hack

Abstract: New Jersey was a state divided by slavery. After the Revolution, slavery continued its decline in West Jersey, home of the state's most-fervent abolitionists. But slavery in East Jersey expanded in the years following independence. This paper examines divisions between east and west in the early Republic.

As the smoke dissipated over the war-ravaged state of New Jersey following the American Revolution, the carnage of the previous eight years was evident. Thousands of lives were lost, families were torn apart, forest reclaimed productive farmland, and property everywhere was looted, requisitioned, or in ruins. From this darkness came light. The American Revolution seemingly drove an ideological stake in the hearts of those who wished to deprive liberty to those who were in most need of it - slaves. The Quakers of West Jersey, motivated by moral concerns, initiated an abolitionist movement among their group as early as 1775 . By 1800, there were only 507 slaves living in all of West Jersey. New Jersey Governor William Livingston declared slavery "inconsistent with humanity and Christianity" and freed his two slaves in 1787. Going further, Gloucester County resident, David Cooper, acknowledged "that blacks are born equally free with whites; it is declared and recorded as the sense of America." Amid the chaos of the post-war period, more slaves escaped from their masters than during any other period in New Jersey's history. Like most other northern states, New Jersey 
appeared to be on the verge of ending slavery. Yet politically, New Jersey

wavered, even as all other northern states abolished slavery by $1803{ }^{1}$

In West Jersey, a strong current of anti-slavery sentiment - initiated by

Quakers - pushed the number of slaves downward. Often perceived as a

conservative, the early movement to end slavery in this area was indeed radical.

Abolitionists in West Jersey visited slaveholders, formed county abolition

societies, provided legal protection for wrongfully enslaved African Americans,

and petitioned the state and federal governments for an end to slavery. The

abolition impulse, however, failed to move East Jersey residents. Trapped between

the state's slaveholders and abolitionists were the slaves themselves. For them, the

Patriot success proved to be both a blessing and curse. Many more slaves were

freed than ever before in New Jersey, but at the same time the number of slaves

overall increased (all in East Jersey). Freed slaves faced difficult economic

prospects and entrenched racism in East and West Jersey. Foreshadowing the

aftermath of the Civil War in the American South, slaves who were freed in the

North received "nothing but freedom."2

\footnotetext{
${ }^{1}$ Theodore Sedgewick, A Memoir of the Life of William Livingston: Member of Congress in 1774, 1775, and 1776; Delegate to the Federal Convention in 1787, and Governor of the State of New Jersey from 1776 to 1790 (J. \& J. Harper, NY, 1833), 400-401; Peter O. Wacker, Land and People, A Cultural Geography of Pre-industrial New Jersey: Origins and Settlements Patterns (New Brunswick, NJ, 1975), 415; David Cooper, A Serious Address to the Rulers of America on the Inconsistency of Their Conduct Respecting Slavery, in Bulletin of Friends' Historical Association, 1937, v. 26, 46.

${ }^{2}$ The earliest histories of the demise of slavery in the North stress political institutions and law. See, Henry S. Cooley, A Study of Slavery in New Jersey (Baltimore, MD, 1896). For the next sixty years, historians stressed the rise of capitalist values in the North brought about the end of slavery. See, Simeon Moss, "The Persistence of
} 


\title{
The Expansion of Slavery in East Jersey
}

\author{
In 1785, John Stryker was just one of twenty-six slaveholders in
}

Bridgewater Township, Somerset County. A Patriot of Dutch descent, he had seen

his fair share of war. British raiders had carried off most of his livestock, and the

Continental Army had requisitioned his cart, horse, and sundry other items.

Stryker's 286-acre plantation was typical of the East Jersey slave-owner. Before

the war, his farm produced enough profit to purchase some land adjacent to his

property and several slaves. Stryker, his wife, three young children, and slave

family of four lived on his property and produced a variety of wheat, grains, and

vegetables for his household and local consumption. Now it lay in ruins and

Slavery and Involuntary Servitude in a Free State, 1685-1866," Journal of Negro History 25 (1950), 289-314 and Mary S. Lock, Anti-Slavery in America (Boston, 1901). As an emphasis on republicanism and ideology took hold during the 1950s and 60's, historians began to merge the economic and ideological concerns regarding the end of slavery in the North. See, Arthur Zilversmit, "Liberty and Property: New Jersey and the Abolition of Slavery," New Jersey History 88 (Winter 1970) and his more comprehensive work, The First Emancipation: The Abolition of Slavery in the North, (Chicago, IL, 1967). David B. Davis presented the most complex argument for the decline of slavery as an institution. He contends that libertarian rhetoric, a stress on morality by religious groups (particularly Quakers), as well as a shift towards capitalist labor relations worked together to create an anti-slavery social, political, and cultural turn. See David B. Davis, The Problem of Slavery in the Age of Revolutions, 1770-1823 (New York, NY, 1975). Historians have attacked Davis's work by Thomas L. Haskell and John Ashworth, each taking a shot at Davis's contention that anti-slavery was a part of a self-interested group, or more importantly, his Marxist overtones. Haskell maintains that antislavery was more of a "cultural" project than a class-driven agenda. Ashworth buttresses Davis's argument that "capitalist morality" emerged in the U.S., which emphasized family values and free agency, the antithesis of slavery. See Thomas Bender, ed., The Anti-Slavery Debate: Capitalism and Abolitionism as a Problem in Historical Interpretation (Berkley, CA, 1992). Seymour Drescher's definitive study of abolition clearly shows that economics were not always the catalyst for the demise of slave societies. In his opinion, humanitarianism and social activism shifted public opinion from believing slavery to be a moral good to an abhorrent evil. See Seymour Drescher, Econocide: British Slavery in the Era of Abolition (Pittsburgh, PA, 1977) and Abolition: A History of Slavery and Antislavery (Cambridge, UK, 2009). Recently, Christopher L. Brown argues that a yearning for moral worth following the defeat of the American Revolution drew citizens toward antislavery. See Christopher L. Brown, Moral Capital: Foundations of British Abolitionism (Chapel Hill, NC, 2006). Gary Nash, Jean Soderlund, Graham R. Hodges, Ira Berlin, and Shane White have shown the complexity of slavery's demise in Pennsylvania, East Jersey, and New York respectively. All emphasize shifting economic priorities among whites and an emphasis on libertarian ideology. See Gary Nash and Jean Soderlund, Freedom by Degrees: Emancipation in Pennsylvania and its Aftermath (New York, NY, 1991); Graham R. Hodges, Root and Branch: African Americans in New York \& East Jersey (Chapel Hill, NC, 1999); Ira Berlin, Many Thousands Gone: The First Two Centuries of Slavery in North America (Chapel Hill, NC, 1998); Shane White, Somewhat More Independent: The End of Slavery in New York City, 1770-1810 (Athens, GA, 1991). 
Stryker fell on hard times. Unable to support himself, in December of 1785,

Stryker advertised the sale of one of his slaves: "A Negro man, about 23 years of age, brought up to farming, in full health." His slaves, who had lived on his farm for more than seven years, were the first casualties of the post-war slavery in New Jersey. Ten years later, Stryker regained his social and economic standing in the community, and while many northerners chose to employ free-wage laborers, Stryker chose to purchase slaves. ${ }^{3}$

The historiography of slavery in the North often emphasizes the dramatic decline of slavery between 1784 and 1804. Yet in East Jersey slavery flourished. Was labor-demand the only reason for the increase of slaveholders and slavery? In places like Bergen and Monmouth County, the number of slaves more than doubled from 1772 to 1800 . The number of slaveholders increased from approximately 3,500 in 1772 to 5,500 in 1800 . In Bergen County, there were 203 slaveholders in 1784 -- that number more than doubled to 413 by 1800 . Nearly all of these new slaveholders resided in East Jersey. ${ }^{4}$

\section{East Jersey Slave Population 1772-1800}

\footnotetext{
${ }^{3}$ Inventories of Damages by the British and Americans in New Jersey, 1776-1782, Claim 34, New Jersey State Archives, Trenton, NJ; New Jersey Tax Ratables (Duplicates), 1768-1846, New Jersey State Archives, Trenton, NJ, reel 17; The New Jersey Gazette, 12/12/1785, 3.

${ }^{4}$ Graham Hodges is the only historian to note an increase in slaves in the area, yet he gives no explanation as to why this was. Gary Nash and Ira Berlin both note the slow process of emancipation in the North, but neither discuss the resurrection of slavery in East Jersey. Several New York Counties also saw an increase in the number of slaves. See Hodges, 162-186; Berlin, 228-255. For general demographic information see, Peter O. Wacker, Land and People, A Cultural Geography of Pre-industrial New Jersey: Origins and Settlements Patterns (New Brunswick, NJ, 1975), 415-416.
} 


\begin{tabular}{|c|c|c|c|}
\hline County & 1772 & 1800 & Change \\
\hline Bergen & 1,152 & 2,825 & $+1,673$ \\
\hline Essex & 758 & 1,521 & +763 \\
\hline Hunterdon & 1,095 & 1,220 & +125 \\
\hline Middlesex & 1,094 & 1,565 & +471 \\
\hline Monmouth & 1,107 & 1,633 & +526 \\
\hline Morris & 367 & 775 & +408 \\
\hline Somerset & 1,467 & 1,863 & +396 \\
\hline Sussex & 285 & 514 & +229 \\
\hline Total & 7,325 & 11,916 & $+4,591$ \\
\hline \multicolumn{4}{|c|}{$\begin{array}{l}\text { Source: Demographic information was compiled from census information and New Jersey tax } \\
\text { ratable. See Peter O. Wacker, Land and People, A Cultural Geography of Pre-industrial New } \\
\text { Jersey: Origins and Settlements Patterns (New Brunswick, NJ, 1975), 415-416 and New Jersey } \\
\text { Tax Ratables (Duplicates), 1768-1846, New Jersey State Archives, Trenton, NJ. These numbers } \\
\text { are approximate, since ratable years are missing for some townships, especially before the } 1790 \\
\text { Federal Census. }\end{array}$} \\
\hline
\end{tabular}

For men like Stryker and his slaves, the aftermath of the American Revolution posed new challenges. Improved land assessed on tax records dropped in every county, but Monmouth, Middlesex, and Bergen seemed to suffer the most. In most townships, the drop in productive land reached nearly 30 percent. Many white laborers - including indentured servants and apprentices - rushed off to war and most never returned. European migration evaporated during the war and did not pick up again until the 1790s. This was not just a critical period for the 
American political system; this was a critical period for men like John Stryker.

They had to find labor or face ruin. Because of the dearth of laborers, the cost for labor, especially during harvest, was high. In 1770, a farmer could hire a worker for $£ 0.1 .3$ per day, in 1788 it reached $£ 0.4$.6. Labor demands continued to be high for the next decade. In 1797, Julian U. Niemcewicz, a traveler from Poland who married Governor Livingston's niece, "hired hands are expensive and hard to get." In the Paterson textile mills, it was reported, "three-quarters of [the] machines lay idle because of lack of hands."

With European migration stunted, East Jersey planters increasingly relied on slaves for their labor demands. In 1798, Col. Erkuries Beatty of Princeton purchased a fourteen-year-old boy named Abram. The following year he bought three "black people...Bristol and Mary, his wife, with their child Joseph." Although he had employed white cottager families and European laborers for much of his life, he actively sought slaves for several reasons. First, he found the availability of free laborers unpredictable, especially during peak harvest time. Every year around September, he seemed to express "anxiety." Second, he loathed the high price paid for wage laborers. Beatty surely was a proto-capitalist. He had

\footnotetext{
${ }^{5}$ John J. McCusker and Russell R. Menard conclude that the overall productivity for the American economy dropped $46 \%$ below pre-war levels. In comparison, the Great Depression of the 1930s saw productivity drop 48 percent. John J. McCusker and Russell R. Menard, The Economy of British America, 1607-1789 (Chapel Hill, NC, 1985), 369-377. For the decline in improved land see, Peter Wacker and Paul G. E. Clemens, Land Use in Early New Jersey: A Historical Geography (Newark, NJ, 1995), 104, 214-229. Tunison/Long Papers, Somerset County Historical Society, Bridgewater, NJ. For the Niemcewicz quote, see Metchie J. E. Budka, ed., Under Their Vine and Fig Tree: Travels through America in 1797-1799, 1805 with Some Further Account of Life in New Jersey (Elizabeth, NJ, 1965), 26, 222.
} 
his eye fixed on commodity market trends and planted accordingly; he also rationalized the best means of maximizing labor. By the 1790s and for the remainder of his life, slaves seemed to be the most advantageous form of labor. Unlike Pennsylvania, where Paul G. E. Clemens and Lucy Simler show convincingly farmers' preferences for free wage or short-term contractual labor, many East Jersey and New York farmers opted for slaves. ${ }^{6}$

Not only were many East Jersey residents convinced that slaves were a more reliable labor option than free laborers, slaves augmented their ability to maintain their class status. In 1784 in Bergen County, slightly more than 200 slaveholders held land averaging around 150 acres, compared to 1354 non-slaveholders who possessed 56 acres. By 1802, 400 slaveholders averaged the same amount of acreage, while 2000 non-slaveholders possessed just 35 acres. In both East and West Jersey, slave owners were generally better off than their non-slaveholding neighbors were, a pattern seen in nearly every society with slaves. With 90 percent of arable land already under cultivation in 1784 , there were few options for farm

\footnotetext{
${ }^{6}$ Erkuries Beatty, Farm Journal, 1797-1800, New-York Historical Society. Beatty was a Presbyterian, a Revolutionary War officer and a member of the Federalist Party. Harry B. and Grace M. Weiss, Colonel Erkuries Beatty, 1759-1823: Pennsylvania Revolutionary Soldier, New Jersey Judge, Senator, Farmer, and Prominent Citizen of Princeton (Past Time Press, location unknown, 1958). The scholarship on the development of capitalist labor development is so vast it would be impossible to list all of the works here. I agree with James Oakes' assertion that slaveholders (in this case in the North) operated rationally and with markets in mind, not just within a capitalist framework. See, James Oakes, The Ruling Race: A History of American Slaveholders (New York, NY, 1982) and Eugene D. Genovese and Elizabeth Fox-Genovese, Fruits of Merchant Capital: Slavery and Bourgeois Property in the Rise and Expansion of Capitalism (New York, NY, 1983), 3-33. Paul G. E. Clemens and Lucy Simler, "Rural Labor and the Farm Household in Chester County, Pennsylvania, 1750-1820," in Stephen Innes, ed., Work and Labor in Early America (Chapel Hill, NC, 1988), 106-143. Gary Nash and Jean Soderlund do show an increase in the use of slave labor in the Pennsylvania counties that bordered Maryland. See, Nash and Soderlund, 4.
} 
owners to increase profits. Furthermore, one could no longer successfully employ

land holdings as a criterion to measure of one's wealth. Land scarcity was a

constant problem in the post-Revolutionary period, sending many to frontier. ${ }^{7}$

One way to increase profits in an agricultural economy was to hire slaves

out. The post-revolutionary period saw an explosion of "slave for hire"

advertisements. A survey of these advertisements shows that slave masters often

noted the versatility of their slaves. Typical advertisements announced, "[For] hire

a negro wench...who is a good at country business." John Droulliard of Trenton

Ferry advertised his "Young Negro Man...to have him to a farmer where he might

learn to plough and the farming business." The amount the slave owner could reap

from renting labor depended on the skill-set of the slave; on average, an owner

could fetch a third or more of the value of the slave per year. With the cost of an

adult slave nearly $\$ 300$ by 1800 , the rewards were substantial. Even during the

post-war economic quagmire, slave owners - if they could afford it - had a stake in

holding onto their slaves. ${ }^{8}$

\footnotetext{
${ }^{7}$ The number of slaveholders in each of East Jersey's counties saw an increase in the number of slaveholders. For example, in Bedminster Township, Somerset County, the number of slaveholders increased from 23 in 1745 to 52 in 1800. Hodges, Slavery, Freedom and Culture, 51-52.

${ }^{8}$ Seth Rockman's detailed analysis of Baltimore shows how rapidly the slave-hiring business expanded in cities, where business connections were in close proximity Cities such as Charleston, New York, and Philadelphia also saw an increase in slave hiring, yet no historian has included the countryside in their analysis. See, Seth Rockman, Scraping By: Wage Labor, Slavery, and Survival in Early Baltimore (Baltimore, MD, 2009), 57-67; Jonathan D. Martin, Divided Mastery: Slave Hiring in the American South (Cambridge, MA, 2004); Edgar J. McManus, A History of Negro Slavery in New York (Syracuse, NY, 1964), 49-57. "Slave for Hire" ads posted in New Jersey, New York, and Pennsylvania newspapers. The Diary or Loudon's Register; 8-17-1792, New York, NY; The True
} 


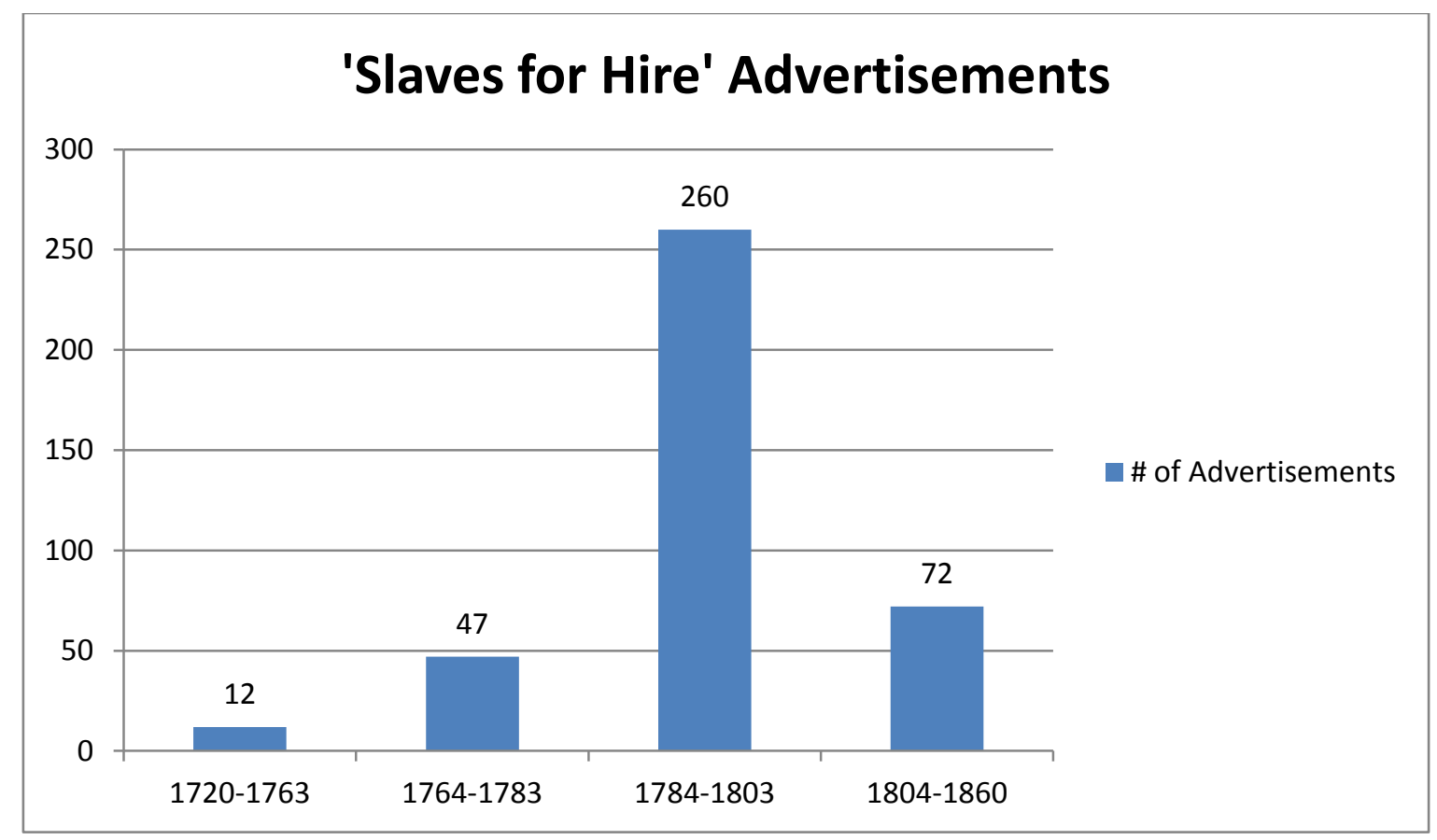

As the number of slaveholders expanded, slaveholding continued to be multi-generational. Many of the same surnames that appeared in the colonial period surface as slaveholders in the early national period. Of the 138 slave owners who left a will in the 1790s, 55 (39.9 percent) had parents and grandparents who owned slaves. For example, the Schencks, Van Houtens, and Banta families, all of Dutch descent, show the persistency of slaveholding within a family unit. Their wills, dated to 1719 , show each family owning at least two slaves - Schenck owned 14 slaves, an anomaly even for East Jersey. As each family expanded, the number of slaves they owned remained stable. In 1794, Garrett Schenk noted, “Men, James, Joe, Moses. Boy, Sam. Girls, Sid, Judith, Patt, Bett, Hannah. Negro wenches, Cate, Sal, Patt, Dinah" as his chattel property. Twenty-eight years 
earlier, Garret's father Roloef, bequeathed 13 slaves his son Garret, and 40 years

earlier, the first Schenk's will notes two slaves, a man and woman. Although

common in the American South, historians of slavery in the North rarely

characterize multi-generational slave owning families holding multi-generations of

slaves as common. This was not just a pattern within the Dutch community, but in

the Anglo community as well. To no surprise, multi-generational slaveholding

appeared to have been stronger in East Jersey than in West Jersey. Only $11 \%$ of

West Jersey slave owners in the 1790s had relatives who owned slaves in the

previous 70 years. Furthermore, since owning and hiring out slaves allowed

farmers to own small homesteads, East Jersey slaveholders tended to remain close

to their ancestral homes. This had a profound effect on maintaining family

cohesion, especially for slaves. ${ }^{9}$

\footnotetext{
${ }^{9}$ The persistency of slaveholding was probably much higher, but tax ratables do not exist for most of the prerevolutionary period. The analysis in this paragraph was culled from William Nelson, ed., Documents Relating to the Colonial History of the State of New Jersey, Vol. 23, Calendar of New Jersey Wills, Vol. I, 1670-1730 (Patterson, NJ, 1901); A. Van Doren Honeyman, ed., Documents Relating to the Colonial History of the State of New Jersey, First Series, Vol. 30, Calendar of New Jersey Wills, Administrations, Etc, Vol. II, 1730-1750 (Somerville, NJ, 1918); A. Van Doren Honeyman, ed., Documents Relating to the Colonial History of the State of New Jersey, First Series, Vol. 32, Calendar of New Jersey Wills, Administrations, Etc, Vol. III, 1751-1760 (Somerville, NJ, 1924); A. Van Doren Honeyman, ed., Documents Relating to the Colonial History of the State of New Jersey, First Series, Vol. 33, Calendar of New Jersey Wills, Administrations, Etc, Vol. IV, 1761-1770 (Somerville, NJ, 1938); A. Van Doren Honeyman, ed., Documents Relating to the Colonial History of the State of New Jersey, First Series, Vol. 34, Calendar of New Jersey Wills, Administrations, Etc, Vol. V, 1771-1780 (Somerville, NJ, 1939); Elmer T. Hutchinson, ed., Documents Relating to the Colonial, Revolutionary, and PostRevolutionary History of the State of New Jersey, First Series, Vol. 35, Calendar of New Jersey Wills, Administrations, Etc, Vol. VI, 1781-1785 (Trenton, NJ, 1939); Elmer T. Hutchinson, ed., Documents Relating to the Colonial, Revolutionary, and Post-Revolutionary History of the State of New Jersey, First Series, Vol. 36, Calendar of New Jersey Wills, Administrations, Etc, Vol. VII, 1786-1790 (Trenton, NJ, 1939); Elmer T. Hutchinson, ed., Documents Relating to the Colonial, Revolutionary, and Post-Revolutionary History of the State of New Jersey, First Series, Vol. 38, Calendar of New Jersey Wills, Administrations, Etc, Vol. VIII, 1791-1795 (Trenton, NJ, 1942); Elmer T. Hutchinson, ed., Documents Relating to the Colonial, Revolutionary, and Post-Revolutionary History of the State of New Jersey, First Series, Vol. 39, Calendar of New Jersey Wills, Administrations, Etc, Vol. IX, 17961800 (Trenton, NJ, 1943).
} 
During the early national period, the Atlantic slave trade to New York and Philadelphia - the primary slave trading ports in the Mid-Atlantic - evaporated. Legislators in New York and New Jersey decided that "the barborous custom of bringing the unoffending Africans...into a state of slavery" was dangerous to "liberty." After March 26, 1786, those who brought slaves into New Jersey from Africa could be fined $£ 50$, while bringing in slaves who had not been enslaved before 1776 were to be fined $£ 20$. This was the first time the General Assembly took up the issue of slavery, and the vote apparently broke down upon regional lines. Of course, this was not borne out of pure desire to end slavery for the sake of justice. The law stated clearly that it was implemented so "that white labor may be protected." Only two transatlantic ships arrived in Philadelphia between 1784 and 1804 with 32 slaves in total; no ships sailed to New York. ${ }^{10}$

The closing of the Atlantic slave trade in the region had a significant effect on New Jersey. First, it showed that at least some lawmakers held the primacy of white labor (free) over that of slave labor (unfree). This was nothing new, since various legal bodies since the 1630 s tried to establish a "white" labor system. However, every attempt failed, including the passage of high tariffs on the importation of slaves early in the century. Second, it reinvigorated a sectional

\footnotetext{
${ }^{10}$ For slave trade information see, http://www.slavevoyages.org/tast/database/search.faces accessed on 6/11/11. "barborous custom" quoted in Oscar Renal Williams, African Americans and Colonial Legislation in the Middle Colonies (New York, 1998), 89. "white labor" Act of the General Assembly of the State of New Jersey, 1788 (10 session), 239.
} 
divide in the state: East Jersey residents increasingly relied on the value and profits derived from slavery, while West Jersey residents vehemently opposed the institution. Finally, it transformed the demography of slavery in New Jersey. By 1800 , virtually every slave in the state was native born. ${ }^{11}$ Unlike the closing of the slave trade nationwide in 1808, which saw slave prices skyrocket, the price of slaves in New Jersey remained relatively steady. Why? A spirited intra-state and more limited coastal slave market developed to offset any loss in the African trade. The "Act to prevent the Importation of Slaves into the State of New-Jersey" of 1786 was strengthened in1788, but both bills only addressed the direct African slave trade. Slaves were still transshipped from the Caribbean or brought from neighboring states, which represented the vast majority of slave imports into the region since the colonial period. ${ }^{12}$

Yet, even the Caribbean slave trade seemed to diminish. Because of British trade restrictions after the war; access to the English-speaking islands was limited. Newspapers show only four ads listing slaves for sale with Caribbean origins, and

\footnotetext{
11 "An Act to prevent the Importation of Slaves into the State of New-Jersey, and to authorize the Manumission of them under certain Restrictions, and to prevent the Abuse of Slaves," March 2, 1786, Acts 10th G.A. 2nd sitting, CXIX, p.239-242. Most northern states (except Rhode Island) had implemented laws that banned or put prohibitive restrictions on the trade. For the slave trade to New York, New Jersey, and Pennsylvania during this period see, http://www.slavevoyages.org/tast/database/search.faces. For racial formation and whiteness see Thelma Wills Foot, Black and White Manhattan: The History of Racial Formation in Colonial New York City (New York, NY, 2004) and David R. Roediger, The Wages of Whiteness: Race and the Making of the American Working Class (New York, NY, 2007).

12 "An Act to prevent the Importation of Slaves into the State of New-Jersey, and to authorize the Manumission of them under certain Restrictions, and to prevent the Abuse of Slaves," March 2, 1786, Acts 10th G.A. 2nd sitting, CXIX, 239-242. A Supplement to an Act, entitled 'An Act to prevent the Importation of Slaves into the State of New-Jersey . ..,"' Nov.26, 1788, Acts 13th G.A. 1st sitting, CCXLIV, 486-488. 1788 law is more thoroughly discussed in Lee Callegard, "The Negro's Legal Status in Pre-Civil War New Jersey," New Jersey History 85 (FallWinter 1967).
} 
merchants' account books in the region show no Caribbean slave trading activity. Regardless, New Jersey, New York, and Pennsylvania newspapers were flush with ads offering slaves for sale. Between 1789 and 1794, slave owners published 2,467 slave sale ads in the Mid-Atlantic region, 103 attributed to New Jersey residents. This exceeded the number of slave sale ads published throughout the entire colonial and Revolutionary periods. Although it is impossible to know the final destination of the purchased slaves, there is evidence to suggest that they remained local. For example, Rulif Traphagen, the administrator of an estate, put a "negro wench up for sale" in 1790 in hopes of finding a local buyer because "her objections to leave her husband." There appeared to be a vigorous market for slaves in the region. ${ }^{13}$

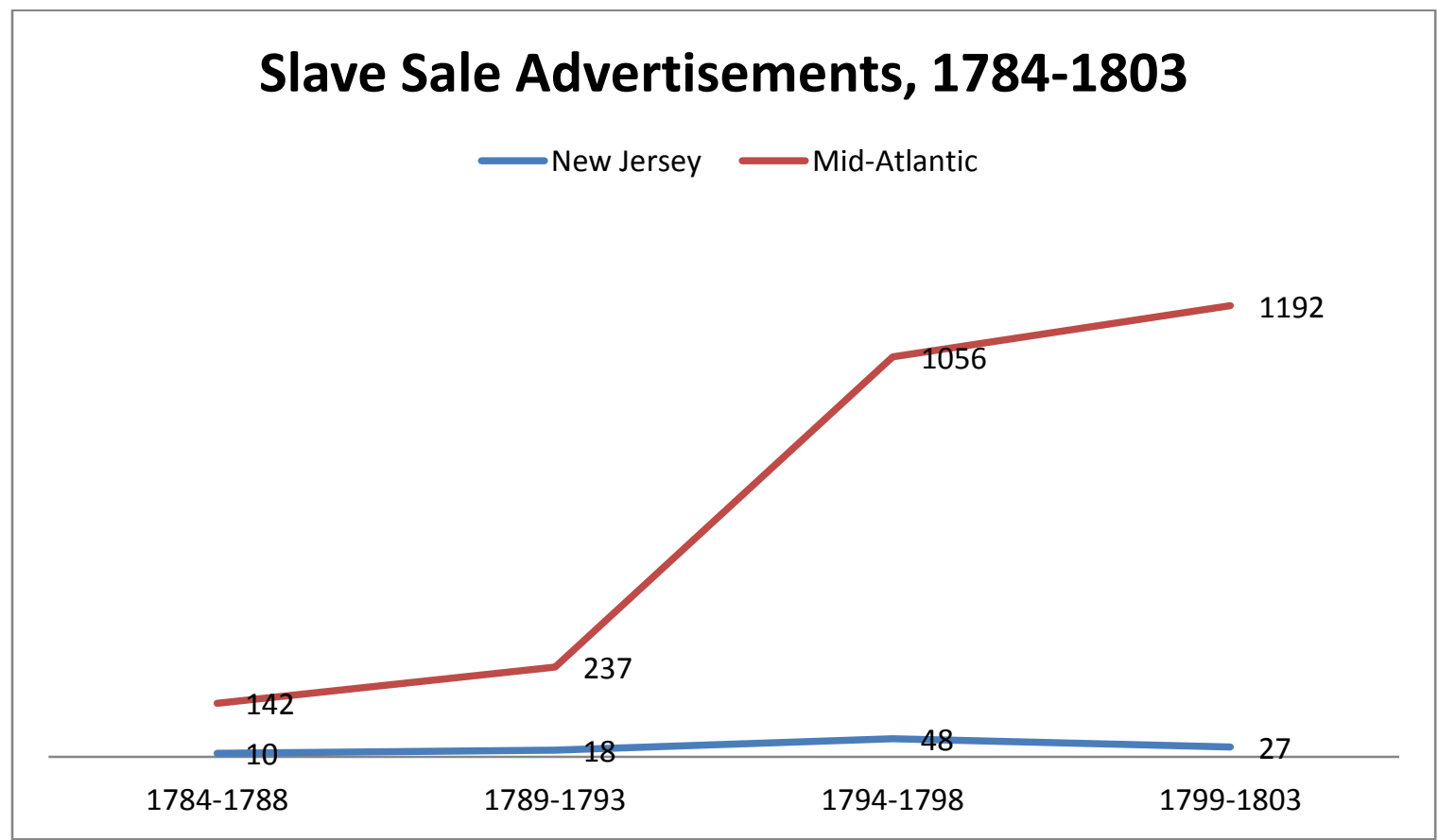

\footnotetext{
${ }^{13}$ For slave sale advertisements see, "Slave Sale Advertisement" Graph above. "negro wench up for sale" NewJersey Journal, 9/22/1790, Elizabethtown, NJ.
} 
Source: I conducted a keyword search in 122 newspapers published in the Mid-Atlantic region during this period. America's Historical Newspapers, Readex, 6/10/09. For New Jersey I searched: Burlington Advertiser, New-Jersey Gazette, Federal Republican, Federal Republican, New-Jersey Journal, Genius of Liberty, Jersey Chronicle, Political Intelligencer, Centinel Of Freedom, Trenton Federalist, and True American.

In 1788 , the state legislature restricted slave owners from removing slaves that had resided in the state for more than twelve months. The law required that the slave give his/her permission if a master wanted to leave the state with his slaves. What is astonishing is the number of slaves who consented to leaving the state. Surviving records show an extraordinary number of slaves assenting to their removal from New Jersey to South and West. As Jim Gigantino has shown, 41 percent of those giving consent for removal from the state ended up in the Deep South. Although strong relational bonds may have influenced some slaves to agree to their removal, it was more likely that coercion and violent reprisals were a more powerful motivator. For example, when Sussex County resident Ann Davison married William Davison of New Orleans, she arranged to move to Louisiana. Chloe, Ann's slave, had a son who lived nearby in New Jersey, yet she assented to her removal to the South. It is hard to believe that a mother would willingly agree to part from her child unless coerced. There is no evidence in the West Jersey manumission records of "voluntary" slave removal. ${ }^{14}$

\footnotetext{
${ }^{14}$ For slave removals see Jim Gigantino, "Freedom and Unfreedom in the Garden of America: Slavery and Abolition in New Jersey, 1770-1857," Ph.D. diss., University of Georgia, 2010, 163-170. Bergen County Clerk's Office Deeds, 1715-1901, New Jersey State Archives, Trenton, NJ; Monmouth County Clerk's Office Deeds, 16651899, New Jersey State Archives, Trenton, NJ. For the expansion of slavery during this period see, Stephen Deyle, Carry Me Back: The Domestic Slave Trade in American Life (New York: Oxford University Press, 2005) and Adam
} 
Even as slaves trickled out of the state, the number of slaves multiplied in East Jersey, mainly through natural increase. The number of slaves and slaveholders was increasing rapidly through the eighteenth century. With the expansion of slavery in East Jersey, the proximity between slaveholding households also shrunk. Overall, the average distance between slaveholding households in East Jersey dropped from six miles in 1745 to four miles in 1800. In some counties, such as Bergen, the average distance dropped from three to 1.5 miles. The composition of slaveholding households was still small - on average 2.3 slaves per household - compared to the American South. As Brenda Stevenson has shown in Loudon County, Virginia, the composition of the household and proximity to potential mates was the strongest indicator of initial familial success. However, death, a weakened financial situation, or whim of a master (as seen with slave removals) always had the potential to destroy the family. Regardless, the expansion of slavery allowed for greater access to potential mates than ever before. Close proximity also allowed for stronger ties to friends and strengthened the slave neighborhood. ${ }^{15}$

Rothman, Slave Country: American Expansion and the Origins of the Deep South (Cambridge, MA, 2004), chpt. 1. Louisiana seemed to be the most prominent destination for slaves.

${ }^{15}$ Graham Hodges insists that long-distances separated potential mates and hindered family development in the rural North, something Gary Nash and Jean Soderlund also stress. See, Hodges, 17-20; Nash and Soderlund, 23-24. Brenda Stevenson, Life in Black and White: Family and Community in the Slave South (Chapel Hill, NC, 1996), chpt 7. Shane White shows a similar trend in rural New York Counties. See White, 146. 


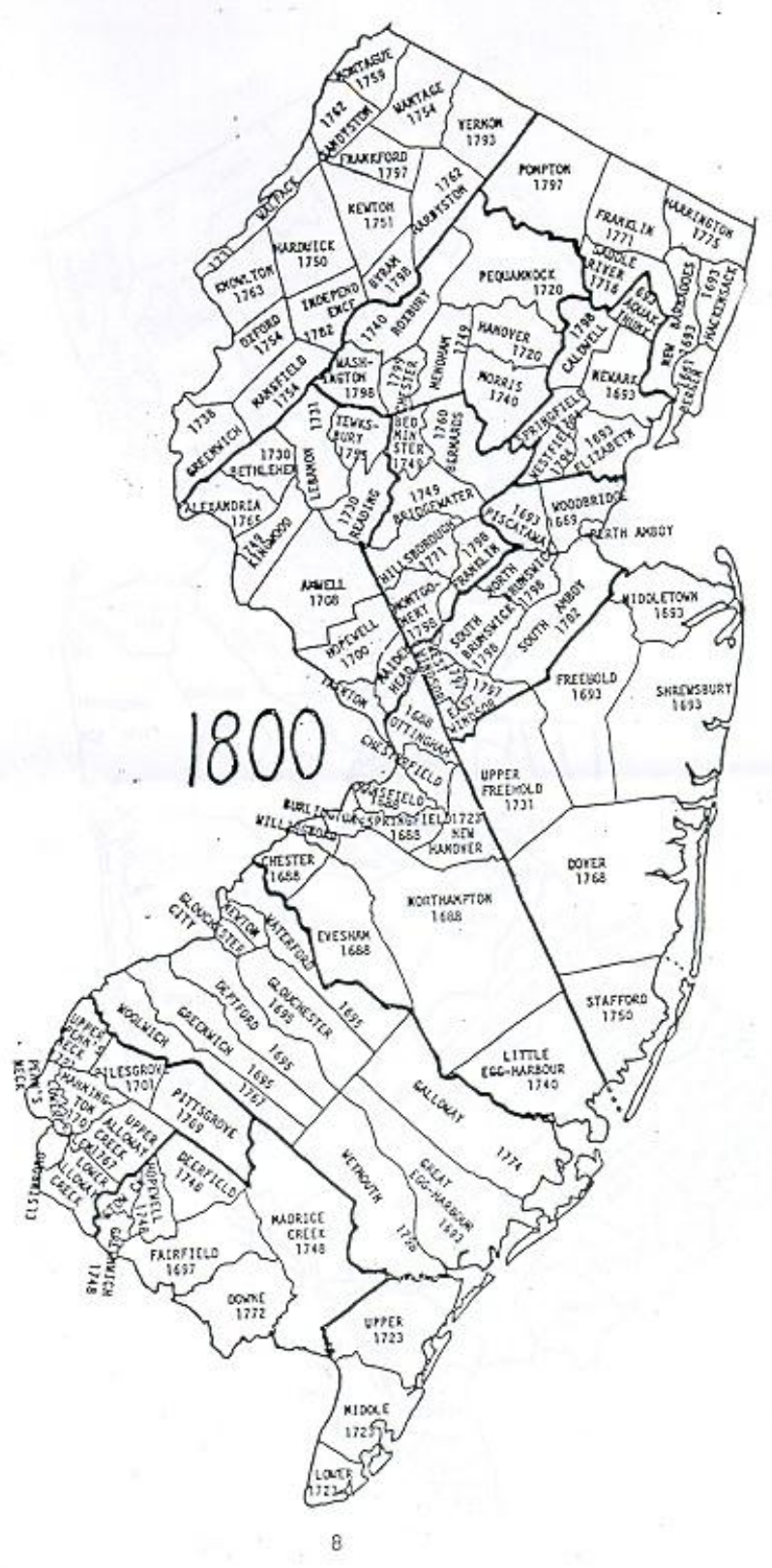

\section{This map shows the dividing line of East and West Jersey and the townships.}

Gender disparities also began to even out. For most of the colonial period, males out-numbered females by a margin of 10 to 8 . This was not nearly as dramatic as Barbados or South Carolina where male/female sex ratios were closer to 2 to 1 . Between 1784 and 1804, an assessment of wills and probate records 
shows that the sex ratio was near even (258 males to 250 females). With more potential mates available, the number of slave unions increased. In one Dutch Reformed congregation in Monmouth County 12 marriages were performed between 1740 and 1780, but between 1784 and 1804 there were 21. Available Anglican, Methodist, Baptist, and Presbyterian Church records also indicate the increased frequency of marriages among slaves. Slaveholders seemed at the very least indifferent to their slaves getting married. In many ways, it served their interests. Just as Europeans perceived marriage amongst themselves as "domestication," slaves were also deemed to be more tempered after marriage. Furthermore, marriage anchored a slave to the master's household and neighborhood. Numerous runaway slave ads noted that a slave had "gone off" with or went in search of a spouse. In order to have some form of legitimacy, ministers required written permission from both slaves' masters before performing the ceremony. Marriage records took note of the names of slave owners, as indicated in a listing in the records of the Westfield Presbyterian Church noted, "Peter, a negro man, belonging to Thomas Woodruff," a record noted, "was married to Dinah, a negro woman, belonging to Dr. Elmer, master's permission." Since slave marriages had no legal recognition until 1809 , slaves had to negotiate with his/her master for permission to marry, and more importantly, the ability to 
spend time with each other. As one runaway slave ad noted: "Absconded with an

18 year-old mulatto girl he pretends is his wife." 16

\begin{tabular}{|ll|}
\hline Slave Household Composition, 1784-1803 \\
\hline Nuclear Family & 30 \\
Single Males & 32 \\
Single Females & 35 \\
Women and Children & 11 \\
Complex Groups & 4 \\
Couples & 22 \\
\hline
\end{tabular}

These numbers are derived from 134 New Jersey wills that identified the living arrangements/relations of slaves within their households. 122 are from East Jersey, 12 are from West Jersey.

Source: Elmer T. Hutchinson, ed., Documents Relating to the Colonial, Revolutionary, and PostRevolutionary History of the State of New Jersey, First Series, Vol. 35, Calendar of New Jersey Wills, Administrations, Etc, Vol. VI, 1781-1785 (Trenton, NJ, 1939); Elmer T. Hutchinson, ed., Documents Relating to the Colonial, Revolutionary, and Post-Revolutionary History of the State of New Jersey, First Series, Vol. 36, Calendar of New Jersey Wills, Administrations, Etc, Vol.

VII, 1786-1790 (Trenton, NJ, 1939); Elmer T. Hutchinson, ed., Documents Relating to the Colonial, Revolutionary, and Post-Revolutionary History of the State of New Jersey, First Series, Vol. 37, Calendar of New Jersey Wills, Administrations, Etc, Vol. VIII, 1791-1795 (Trenton, NJ, 1942); Elmer T. Hutchinson, ed., Documents Relating to the Colonial, Revolutionary, and PostRevolutionary History of the State of New Jersey, First Series, Vol. 38, Calendar of New Jersey Wills, Administrations, Etc, Vol. IX, 1796-1800 (Trenton, NJ, 1943); Elmer T. Hutchinson, ed., Documents Relating to the Colonial, Revolutionary, and Post-Revolutionary History of the State of New Jersey, First Series, Vol. 39, Calendar of New Jersey Wills, Administrations, Etc, Vol. X, 1801-1805 (Trenton, NJ, 1946).

\footnotetext{
${ }^{16}$ Caribbean slave populations generally favored males, but Barry W. Higman found that by 1804 the British Caribbean sex ratio had also begun to even out. See, Barry W. Higman, Slave Populations of the British Caribbean, 1807-1834 (Kingston, Jamaica, 1995), 115-120. The same could be said about Virginia and South Carolina. See, Alan Kulikoff, Tobacco and Slaves: The Development of Southern Cultures in the Chesapeake (Chapel Hill, NC, 1995), 317-371 and Phillip D. Morgan, Slave Counterpoint: Black Culture in the Eighteenth Century Chesapeake and Low Country (Chapel Hill, NC, 1998), 61-82. In rural New England, the small numbers of slaves coupled with large distances between slaveholders made it very difficult to form and maintain families. See, Elise Lemire, Black Walden: Slavery and Its Aftermath in Concord, Massachusetts (Philadelphia, PA, 2004). For marriages, see First Baptist Church (Middletown), Records; 1712-1741, 1785-1796, 1804-1922, marriages, Monmouth County Historical Association, Freehold, NJ; Holmdel First Reformed Dutch Church (Holmdel), Marriage records, volume 8, Monmouth County Historical Association, Freehold, NJ; Old Brick Reformed Church of Marlboro, Marriages, Monmouth County Historical Association, Freehold, NJ; Trinity Cathedral in Newark, Newark, NJ, Manuscript Group 882, box 9. "Gone off" Claypoole's American Daily Advertiser, 10-08-1796, Philadelphia, Pennsylvania. Marriages, Westfield Presbyterian Church, 1759-1840.
} 
The result of increased marriages inevitably produced more slave children. It is very difficult to acquire actual numbers of slave children. Census data are unavailable and tax ratables only note slaves over the age of 16 . What scant evidence is available comes from baptismal records, wills and probates, and slave sales records. Between 1784 and 1804 there was a 27 percent increase in slave children mentioned compared to the previous 20 years. Slave women bore more children than ever before. This post-war trend appears unique to East Jersey compared to other regions in America. Perhaps parents of slaves felt more comfortable in the post-revolutionary environment. In neighboring states such as Pennsylvania, gradual emancipation was underway. Nearly every state in New England abolished slavery. If abolition seemed inevitable in New Jersey, perhaps it seemed a good time to start a family. However, the increased number of slave children only exacerbated white antipathy towards blacks, and heightened racial tensions. One traveler remarked as he made his way through East Jersey on his way to Philadelphia "that negroes are quarrelsome, intemperate, lazy and dishonest... their children are worse." During most of the colonial period, the growth of slavery in New Jersey was attributed to natural increase combined with 
intra-colonial migration and the Atlantic slave trade. In the post-Revolutionary

period, natural increase was the primary reason for the growth of slavery. ${ }^{17}$

The general stability of the slave family, coupled with the increase in slaves and slave-owning households, strengthened the foundations of the slave neighborhood. As a result, the post-Revolutionary period spawned a religious revival among black New Jerseyeans. The number of Quaker meetings held specifically for blacks increased. However, no blacks were allowed into the Society of Friends until 1796 due to the "the spirit of prejudice which had been imbibed on account of colour." Jacob Green, a Presbyterian minister, noted in 1789 that "negros appear at service as never before." Methodists made the largest inroads among New Jersey's slaves. As Nathan Hatch has shown, the Methodist Church's position towards slaves was divided between egalitarianism and racism. This was no different in New Jersey, which most likely inspired African Americans to form Mount Psigah African Methodist Episcopal church in Salem in 1800. Methodists did not stir as much controversy in New Jersey as they did in Virginia. However, since Methodists actively sought to incorporate people of all colors, they found little support among slaveholders. After hearing the preaching of Benjamin Abbot, Phyllis, a slave of a woman named Mrs. Miles, converted to

\footnotetext{
17 "that negroes" Rayner W. Kelsey, ed., Cazenove Journal, 1794: A Record of the Journey of Theophile Cazenove through New Jersey and Pennsylvania (Philadelphia, PA, 1922), 8. Federal census data is not available until 1830 For baptisms see, Elizabeth M. Perincheif, ed., Index to Cemetery Transcriptions, Baptismal, Burial, Church and Marriage Records in the Genealogical Magazine of New Jersey through 1980 (Mount Holly, NJ, 1978). For comparison of slaves children in other areas see, Morgan, 94.
} 
Methodism. Her mistress was "displeased with her conversion" and "made the service of her black slave harder than ever." One Elizabethtown resident complained that his runaway "pretends to be religious, claims to be a Methodist, [and] is a great liar." Historians have concluded that attendance at religious services in white congregations went down significantly during the post-war period. New Jersey slaves appeared to be going through a Great Awakening. ${ }^{18}$ With strong family and community connections, the majority of New Jersey slaves remained with their masters rather than run away. However, at least 179 slaves did attempt to escape during this period, nearly all of them male (only 28 females attempted escape). Only seven runaways absconded from West Jersey. Several reasons attribute to the spike in runaway ads in 1794 and between 1801 and 1803. First, the French government abolished slavery in 1794 and events in Haiti seemed to favor the creation of the first black republic. This expansion of freedom to some, even far away, may have prompted others to run. Pomp, a slave from Morristown, tried to do something that would have been perceived as suicide years earlier: escape to Haiti. Second, New Jersey legislators had been dragging their feet on the passage of a gradual abolition bill. Instead of waiting for

\footnotetext{
${ }^{18}$ Quakers often postponed the question of blacks joining the Society, since they would have to be treated equally and would be eligible to marry their white fellow congregants. It is little surprise that light-skinned women (and only a few) were the only people to be confirmed into the Society. See, Henry Cadbury, "Negro Membership in the Society of Friends," Journal of Negro History 21 (1936), 151-213. Jacob Green Papers, Manuscript Group 579, New Jersey Historical Society, Newark, NJ. For the spread of Methodism see Nathan Hatch, The Democratization of American Christianity (New Haven, CT, 1989); Rhys Isaac, The Transformation of Virginia, 1740-1790 (Chapel Hill, NC, 1982). "pretends" New Jersey Journal, 12/10/1799. Rev. G. A. Raybold, Reminiscences of Methodism in West Jersey (New York, NY, 1849), 45-46.
} 
legislators to act, some slaves ran. But the lure of freedom was only so strong.

Given the choice between liberty or slavery and family, most slaves in New Jersey choose the latter. This choice was an important reason behind the expansion of slavery in East Jersey. ${ }^{19}$

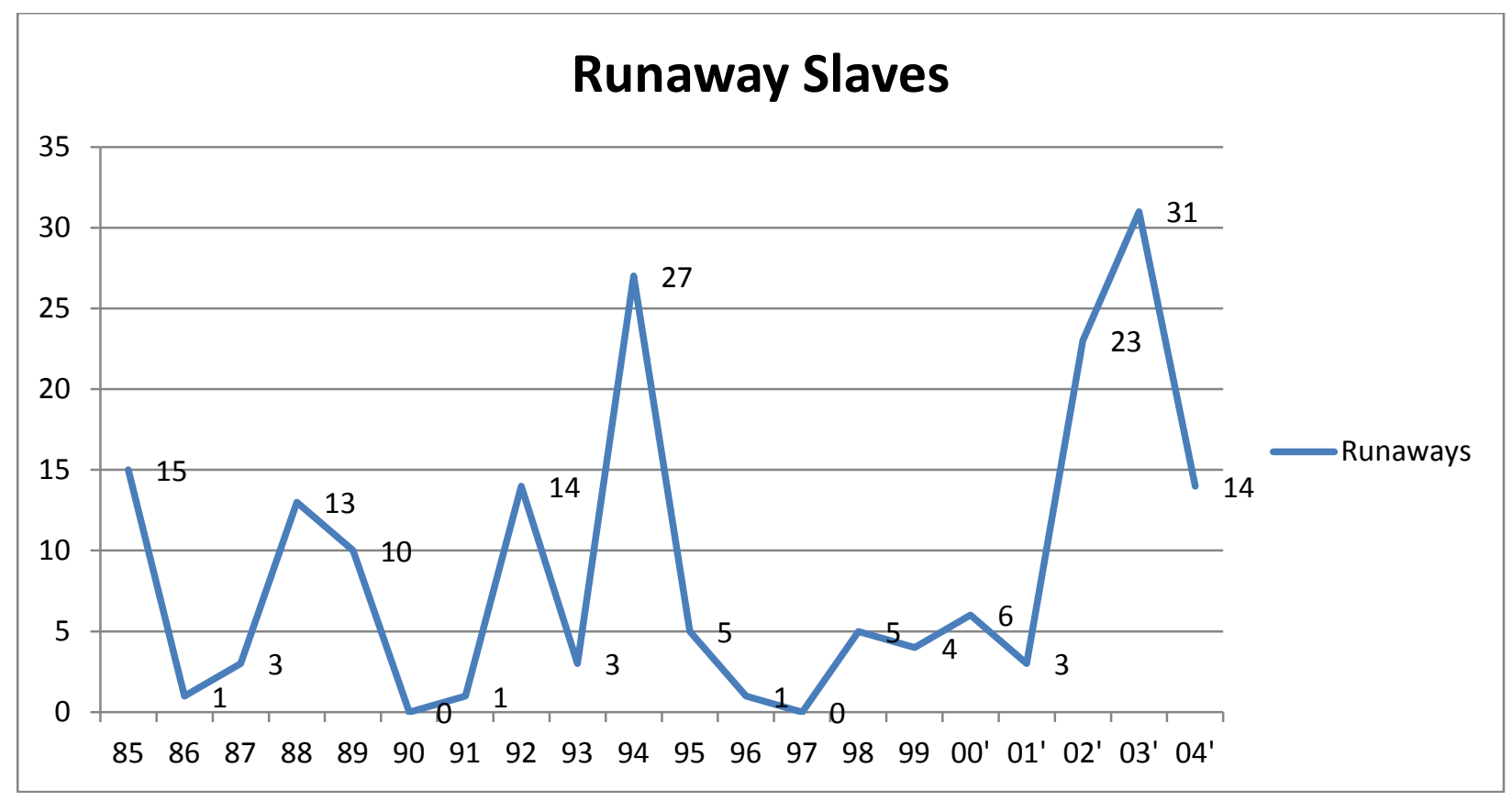

The Haitian Revolution altered slavery in New Jersey as well. The events unfolding in the Caribbean horrified New Jersey slaveholders. Newspapers were filled with horrid descriptions of "negroes...spreading death and destruction around the country, burning and destroying all that falls in their way; every day

\footnotetext{
${ }^{19}$ For New Jersey slave laws see, Marion T. Wright, "New Jersey Laws and the Negro," The Journal of Negro History, 28 (Apr., 1943), 159-178; Paul Axel-Lute, The Law of Slavery in New Jersey: An Annotated Bibliography, http://njlegallib.rutgers.edu/slavery/bibliog.html, October 9, 2009. For NJ Wills, see footnote 9. (Boys), New Jersey Archives, XVI, 56. For Haiti and the spread of the "freedom doctrine" see Ada Ferrer, "Haiti, Free Soil, and Anti-Slavery in the Revolutionary Atlantic," AHR Vol. 117 (1), Feb. 2012, 40-66. For family formation see, Herbert G. The Black Family in Slavery and Freedom, 1750-1925 (New York, NY, 1976); Nash and Soderlund, 3043; and Graham R. Hodges, Slavery and Freedom in the Rural North: African Americans in Monmouth County, New Jersey, 1665-1865 (New York, NY, 1997), 17-21. "Pomp" The New-York Packet, 07/28/1791, New York, NY.
} 
and night we see six, eight and ten different fires." In response, authorities treated all fires with added suspicion. In 1793, a Philadelphia paper published an article entitled "Arson." It begins: "Arson is the crime of slaves and children. Its motive is revenge." Over the next four years, reports of arson increased and slaves suffered the consequences. A slave named Margaret from Bergen County may have been a victim of this slave rebellion paranoia. In 1797, the courts charged her of intentionally burning her masters' property. Although the evidence against her was entirely circumstantial and the only witnesses were slaveholders, the Supreme Court found her guilty and sentenced her to death. ${ }^{20}$

Black Haitians also added to New Jersey's slave population. In 1793, after the burning of Cap François, about 400 Haitian refugees - many with slaves in hand - arrived in the port of Philadelphia and New York. From there the refugees scattered. A small number of them arrived in New Jersey. In Burlington County, the New Jersey Abolition Society census of 1798 noted 47 French slaves, distinguishing them from native-born slaves. They certainly brought with them first-hand news of the events unfolding in the Caribbean. Perhaps this is why

\footnotetext{
${ }^{20}$ For a brilliant treatment of the Haitian Revolution see, Laurent Dubois, Avengers Of The New World: The Story Of The Haitian Revolution (Cambridge, MA, 2005). "Extract of a Letter from a Gentleman in Cape Francois, to His Friend in This City, Dated March 29, 1792," The New-York Journal, \& Patriotic Register (Elizabethtown, NJ) April 28, 1792. State of New Jersey v. Negro Margaret, 1797, New Jersey Supreme Court, Case \# 37209, Trenton, NJ. John Edo, a free white, was convicted a year earlier of misdemeanor arson and was only fined. See, State of New Jersey v. Negro Margaret, 1796, New Jersey Supreme Court, Case \# 35058, Trenton, NJ. “Arson” William Bradford, An Inquiry How Far The Punishment Of Death Is Necessary in Pennsylvania: With Notes And Illustrations (Philadelphia, 1793), 31-32. In Elizabethtown, EJ there were reports of six attempted fires in 1797, see, The Centinel of Freedom (Newark, NJ) February 15, 1797.
} 
runaway slave ads ballooned in 1794. Regardless, within a generation French slaves amalgamated into the region's black community. ${ }^{21}$

The growth of slavery in East Jersey was cause for concern for the region's residents. White hegemony was a common-sense assumption by most East Jerseyeans, but the increased black population seemed to threaten the established order. In Elizabeth, township officials created a committee to see "what further Laws and Regulations are expedient to prevent irregularities and disorderly conduct among slaves." Between 1784 and 1804, 73 violent crimes or cases of theft involving slaves came before the New Jersey Supreme Court, which was more than the previous century. East Jersey slaveholders, many with Dutch roots, had established a rigid patriarchal household structure with conservative values during the colonial period. The Dutch Reformed Church had promoted the ideals of order and obedience to the master of the household, while Dutch communities reinforced these standards through law and custom. The disorder brought on by the American Revolution, with its rhetoric of natural rights and condemnations of tyranny put into question the absolute authority of the master. Disorder seemed to continue after the American Revolution as the economy sputtered and political authority was shaky. The increase in arson and theft, the reality of slaves and

\footnotetext{
${ }^{21}$ For the impact of the Haitian Revolution on Philadelphia's black community see, John Davies, "Class, Culture, and Color: Black Saint-Dominguan Refugees and African-American Communities in the Early Republic," diss. University of Delaware, 2008. The New Jersey Abolition Society conducted a census of African American in West Jersey in 1798; see Timothy Hack, "1798 Census of African-American's in West Jersey," manuscript, Salem County Historical Society, Salem, NJ, 2004.
} 
servants running away, and a perceived diminished sense of deference by inferior members of the household added to the master's status anxiety. In this environment, slave owners (actual and potential) tried to restore order within a turbulent social system. As a mainstay of the Atlantic economy with long historical roots, and with clear hierarchal distinctions, slavery not only served the labor needs of East Jerseyeans, but also served as a partial remedy to perceived patriarchal decline. $^{22}$

\section{The Decline of Slavery in West Jersey}

While the use of slaves expanded in East Jersey, slavery declined rapidly in West Jersey. Although the economic situation in West Jersey following the Revolution was similar to that in East Jersey, other forces worked against the expansion of slavery there. First, the overall white and black population was much smaller than that of East Jersey. Since much of West Jersey is sandy loam, Europeans were reluctant to settle there, preferring cheaper and more arable backcountry land. Pastor Carl Mangus Wrangle noted in 1764, "The country hereabouts has been inhabited only during the last twenty years. Previously there had been only wild, barren ground between Philadelphia and Egg Harbor.” Thirty years later one traveler noted, "all the seashore for three of four miles does not

\footnotetext{
${ }^{22}$ Elizabeth Town Records, Rutgers University Special Collections, New Brunswick, NJ, pg. 31, 6/5/1798. For New Jersey Supreme Court records see, https://wwwnet1.state.nj.us/DOS/Admin/ArchivesDBPortal/SupremeCourt.aspx, accessed 6/12/2009.
} 
have a single dwelling place and there is very little farming." Slaves served their master's interests in bog iron mining and smelting, forest harvesting, and in minor industry such as milling, but these operations were generally small and remote.

Second, the average farm sizes in West Jersey were not nearly as small their northern neighbors. Whereas the mean farm size for a Bergen County resident was 58.3 acres in 1794, the mean farm size of a Burlington County resident was 121.6 acres in 1797. Unlike East Jersey, West Jersey slaveholders could still employ their slaves profitably off their landholdings while preserving their status and wealth. Besides the desire to have a permanent labor source for one's personal needs, the want for slaves was not very strong. Third, the availability of local labor sources made purchasing slaves less appealing. The numbers of "singlemen" listed on township tax ratable - a term designated for laboring men, usually transient, without property - ballooned following the Revolution. Finally, Philadelphia still served as the primary port of entry for European immigrants. If family, neighbors, and local labor options were exhausted, West Jersey residents could easily access the labor markets there. ${ }^{23}$

\section{West Jersey Slave Population 1772-1800}

\begin{tabular}{llll}
\hline County & 1772 & 1800 & Change \\
\hline
\end{tabular}

\footnotetext{
${ }^{23}$ Carl Magnus Andersen, ed., trans., "Pastor Wrangel's Trip to the Shore [1764]." New Jersey History 87 (1969): 5-31, quotations are found on 11-12; Budka, 222; Clemens and Wacker, 219, 227, for labor options see 101-109. Singlemen, New Jersey Tax Lists, 1772-1822, New Jersey State Archives, Trenton, NJ.
} 


\begin{tabular}{llcl}
\hline Burlington & 731 & 188 & -543 \\
Cape May & 111 & 98 & -3 \\
Cumberland & 110 & 75 & -35 \\
Gloucester & 316 & 61 & -255 \\
Salem & 298 & 85 & -213 \\
Total & $\mathbf{1 , 5 6 6}$ & $\mathbf{5 0 7}$ & $\mathbf{- 1 , 0 5 9}$ \\
\hline $\begin{array}{l}\text { Source: } \text { Peter O. Wacker, Land and People, A Cultural Geography of Pre- } \\
\text { industrial New Jersey: } \text { Origins and Settlements Patterns (New Brunswick, NJ, } \\
\text { 1975), 415-416. }\end{array}$ & & \\
\hline
\end{tabular}

Culture also played a strong role in the abandonment of slavery in West Jersey. Although not a majority of the population, the Quakers exercised a tremendous amount of influence in shaping West Jersey society. Quakers were the majority slaveholders through much of the colonial period, but consternation over slave owning grew. By the mid-eighteenth century, West Jersey residents John Woolman and David Cooper gave voice to a growing chorus of abolition-minded Quakers. They were not nascent capitalists advocating the superiority of free-wage labor or as one historian has labeled them "deviant personalities." Their concerns were less about economics - though Woolman would argue that conspicuous consumption and the urge to "get ahead" motivated people to purchase slaves than about morality. Owning slaves not only broke the Golden Rule, but propagated warfare, kidnapping, and violence. Slaveholding broke marriages 
among slaves, promoted polygamy, and worse yet, put the master in charge of his or her slaves' salvation. At the urging of Jersey Quakers, the Society of Friends banned slave trading amongst its group in 1758 and made slave owning a disownable offense by $1776 .^{24}$

\section{Manumissions in Salem County}

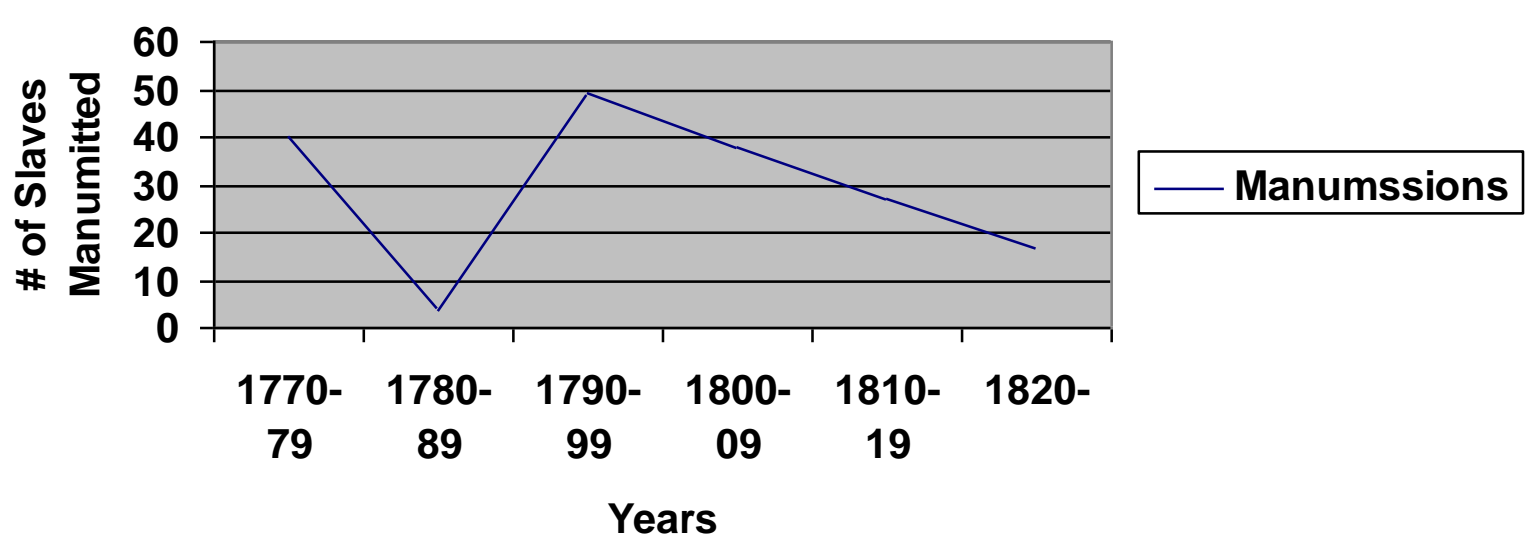

Most West Jersey Quakers manumitted their slaves. A study of wills and manumission records shows that of those who released their slaves between 1784 and 1804, 86 percent were Quakers. Once Quakers freed themselves of the sin of slavery, they advanced a public crusade against the evil. In 1793, Quakers joined with others to form the New Jersey Abolition Society. Every West Jersey county

\footnotetext{
${ }^{24}$ For the cultural influence of the Society of Friends in New Jersey, see Wacker, Land and People, 178-83. Davis, 233-332, quote on p. 324. John E. Pomfret, "West New Jersey: A Quaker Society 1675-1775" The William and Mary Quarterly, Third Series, Vol. 8, No. 4 (Oct., 1951), pp. 493-519. For early Quaker efforts see, John Hepburn, The American Defence of the Christian Golden Rule, or An essay to Prove the Unlawfulness of Making Slaves of Men: By Him Who Loves the Freedom of the Souls and Bodies of All Men (Philadelphia, 1715); Ralph Sandiford, An Examination of the Practice of the Times (Philadelphia, 1729); Amelia M. Gummere, ed., The Journal and Essays of John Woolman (New York, 1922); Thomas P. Slaughter, The Beautiful Soul of John Woolman, Apostle of Abolition (New York, 2008). For efforts to end slavery amongst Quakers in NJ, see Jean R. Soderlund, Quakers \& Slavery: A Divided Spirit (Princeton, NJ, 1985). For the most comprehensive debate on Quakers and slavery, see Bender, ed., The Anti-Slavery Debate.
} 
save Cape May formed a county affiliate. Once again, Quakers dominated the membership rolls. County societies used their expertise in law - lawyers made up significant minority of the members - to seek justice for wrongfully enslaved blacks and petition state authorities to establish an abolition bill. Their efforts were extremely successful. Not only did they create an environment where owning slaves cultural distasteful, they spearheaded both the 1794/98 bills that liberalized the terms in which one could manumit their slaves (a $£ 200$ bond was required beforehand) and the 1804 Gradual Abolition Bill that inevitably ended slavery in New Jersey. One can only imagine what course not only New Jersey history, but American history would have undergone had it not been for New Jersey Quakers and their allies. ${ }^{25}$

\section{New Jersey Abolition Society, Membership}

\footnotetext{
${ }^{25}$ Gloucester County Clerk's Office Slave Records, 1738-1826, NJSA, Trenton, NJ; Burlington County Clerk's Office Deeds, 1785-1901 and Indexes, 1785-1921 \& 1948, Book A, NJSA, Trenton, NJ; Salem County Clerk's, Slave Record Index, Salem County Historical Society, Salem NJ; Cumberland County Clerk's Office Deeds, 17851901 and Indexes, 1785-1952, Book A, NJSA, Trenton, NJ; Cape May County Clerk's Office Deeds, 1692-1901 and Indexes, 1692-1926. Book A and B, NJSA, Trenton, NJ; NJ Wills, 1780-1800. Minutes book, 1789-1809, 17981802, Salem County, New Jersey also manumissions 1800-1849 and marriages by John Nichols 1804-1822, Historic Society of Pennsylvania, Philadelphia, PA; Gloucester County Manumissions of slaves, 1787-1813, 1817-1840, copy at the Gloucester County Historical Society, Woodbury, NJ; Manumission of Slaves, Book B, Burlington County and Burlington County Clerk's Office Deeds, 1785-1901 and Indexes, 1785-1921 \& 1948, New Jersey State Archives, Trenton, NJ; Cape May County manumissions are scattered in throughout their deed books. See, Deed book N, 453, 528; Deed Book T, 23; Deed Book V, 430; Deed book H, 189; Deed book O, p. 367. I have not uncovered any manumission book for Cumberland County.
} 

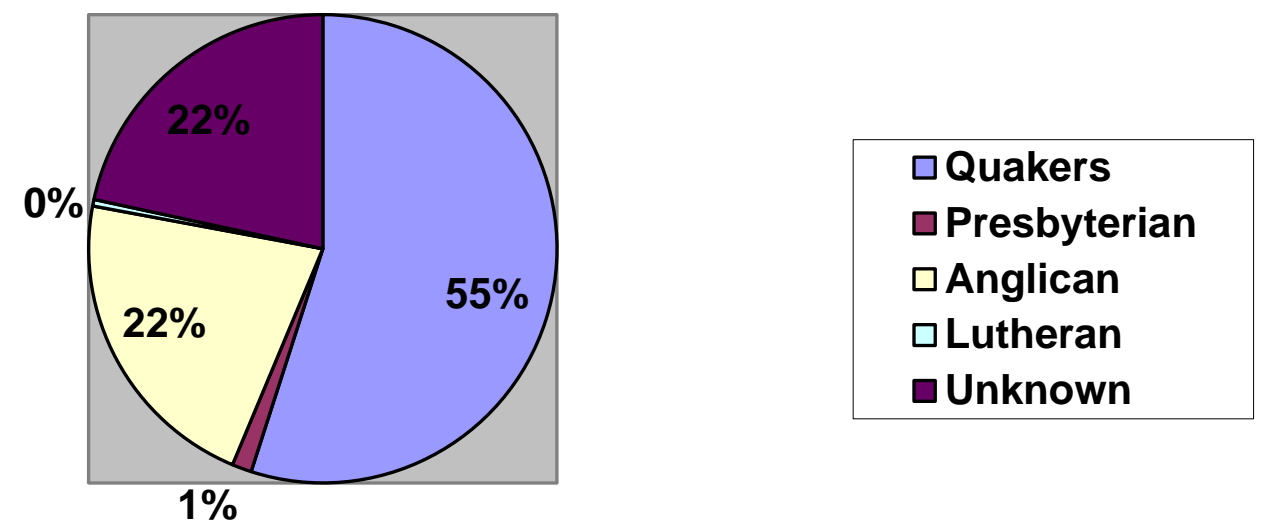

I have identified 224 members who served in various capacities on county and the state abolition societies. See, Pennsylvania Abolition Society Papers, Historic Society of Pennsylvania, Philadelphia, PA; New Jersey Abolition Society Papers, Burlington County Historical Society, Burlington, NJ; Gloucester County Abolition Society Minute Book, Rowan University Special Collections, Glassboro, NJ; Minute Book of the New Jersey Abolition Society, 1793-1809, Haverford College Special Collections, Haverford, PA.

One effective tactic Quaker abolitionists adopted were "calls" to slaveholding neighbors, regardless of their religious profession. John Hunt of Burlington County wrote about one incident in 1789 . "Went to see Joseph Lee not a professor with us on account of his keeping a negro a slave. They seemed deaf to [us]. Negros got free soon after." Quaker Meetings and County Abolition Societies supported the moral suasion approach to ending slavery. Hunt was just one of several dozen West Jersey prophets proselytizing an abolitionist message to slaveholders. Because of their grassroots influence in the community, slavery as an institution quickly dissolved in West Jersey. ${ }^{26}$

\footnotetext{
${ }^{26}$ John Hunt's Journal, Friends Historical Library of Swarthmore College, Swarthmore, Pennsylvania.
} 
Anti-slavery efforts also reached the justice system, putting slaveholders permanently on the defensive. On September 5 1811, Samuel Mickle of Woodbury "went to court... (amongst a multitude) to hear a trial between... a black man named, James Dickinson" and a man named Hathaway who had claimed Dickinson as a runaway from Maryland. The jury was divided 8 to 4 , then after more hours of deliberation; split 7 to 5 in favor of Dickinson. Perhaps one of the jurors understood that the jury was being led to Hathaway's side. Mickle noted, "About 8 this morning 1 of the [jurors] left the rest, crept out at a window and ran off...quickly after which the court was called and the jury was dismissed." Certainly, this was a planned tactic to sabotage Hathaway's claim. How many times could Hathaway continue the cost and expense of going to court? Eight years later, another event crystallized the regions' contempt for slaveholders. Mickle wrote:

Much of ye day spent with ye crowd at ye courthouse in hearing witnesses and arguments in ye case of black Jane BOWYER and her four children claimed as runaway slaves by William JONES of Delaware State who was lately fined in said state $\$ 500.00$ for kidnapping. The Blacks were this evening liberated but ye three witnesses against them imprisoned till further order. One of ye party against said Blacks viz: George DeSHIELD (after ye court adjourned to dine) made escape on John Moore WHITE's horse, lent him, to Gloucester and thence crossed ye river to Philadelphia though pursued by three constables. 
With a hostile legal system, slaveholders knew they had to tread carefully. ${ }^{27}$

Lost in the sources are the many ways that African Americans helped in the abolition of slavery. Denied basic civil rights and meaningful access to institutional support - there were no black members on any of the early abolition societies, free blacks and slaves took matters into their own hands. Abolition societies could not act without the eyes and ears of local blacks, they were of course on the front lines. Dozens of accounts of wrongful enslavement would have gone unaccounted for, had it not been for the courage of "enslaved" men and women to bring their cases to local abolition societies. Moreover, nascent black communities were extremely vigilant in maintaining their freedom. Samuel Mickle noted that when slave catchers arrived in Gloucester County to collect a slave, "one of their assistants, Henry Wright, [was] killed... at Guineatown." Blacks could not solely rely on empathetic whites in their neighborhoods; they knew constant vigilance amongst them was necessary to remain free. ${ }^{28}$

During this period, African Americans in West Jersey were also instrumental in forming the Underground Railroad. Although the Underground Railroad is often associated with the Ante-bellum period, but there is little doubt that black residents with the help of local whites, offered succor for escaped slaves from

\footnotetext{
${ }^{27}$ Ruthe Baker, ed. trans., The Diaries of Samuel Mickle, Woodbury, Gloucester County, New Jersey, 1792-1829, Vol. 1. Gloucester County Historical Society, Woodbury, NJ, 1991, 416. Ruthe Baker, ed. trans., The Diaries of Samuel Mickle, Woodbury, Gloucester County, New Jersey, 1792-1829, Vol. 2. Gloucester County Historical Society, Woodbury, NJ, 1991, 93.

${ }^{28}$ Ruthe Baker, ed. trans., The Diaries of Samuel Mickle, Woodbury, Gloucester County, New Jersey, 1792-1829, Vol. 1. Gloucester County Historical Society, Woodbury, NJ, 1991, 430
} 
Delaware and Maryland well before then. In 1801, Delaware slave owner, John Cochran offered a 60-dollar reward for his escaped slave, who "is gone upcountry to the Jersey's." That same year Robert Tevis and Joseph Cresap advertised jointly, the escape of their two slaves. They noted that "Jim runaway 18 month ago, and says when away, that he lived in Jersey, opposite New-Castle." Court cases also shed light on the fact that African Americans in New Jersey were harboring runaway slaves early on. In several cases brought before local judges in Gloucester and Salem County, the slave catchers all claimed to be recovering slaves for clients in Maryland and Delaware. Certainly, Jim and many like him brought back information to other slaves in his neighborhood: head to West Jersey and you will find safety. ${ }^{29}$

West Jersey also became one of the first and most vigorous "free soil" areas in the Mid-Atlantic. The notion of "free soil" - not to be confused with the Free Soil Party - was recognition by inhabitants in a defined geographic area, that men and women who arrive in this zone are free. The right to property, by a slave master for example, remained subsidiary to the natural right of freedom. Richard S. Newman has shown how Pennsylvania, being a border state, served the role as a predominate "free soil" region for escaped slaves. Ostensibly, Pennsylvania law

\footnotetext{
${ }^{29}$ There is a tremendous amount of folklore surrounding the Underground Railroad in West Jersey. For serious treatments of the Underground Railroad in New Jersey see Wilbur H. Seibert The Underground Railroad: From Slavery to Freedom (New York, 1898; Reprint, New York, 1967); Charles L. Blockson, The Underground Railroad (New York, 1987). "John Cochran"

The Gazette of the United States, July 15, 1801, Philadelphia, PA. “Tevis and Cresap" Poulson's American Daily Advertiser, 11/24/1801, Philadelphia, PA.
} 
helped create the "free soil" region that slaves aspired to. Yet the slave question split local residents, and some authorities often sent slaves back to their owners. West Jersey residents maintained a united front against slavery. Even though federal and state law sanctioned slavery, West Jersey institutions and residents skirted the law and protected slaves. Only after slave owners presented substantial evidence did judges relinquish slaves. Even then, court official would slow the process to a halt in an effort to wear out, and bankrupt the pursuer. ${ }^{30}$

The institution of slavery ended in West Jersey rather quickly, yet most of the social and cultural baggage remained. Former slaves lacked the economic freedoms bestowed to whites. Whites refused to sell land to blacks, an essential component to any successful household. When they did purchase land it was in small parcels (15 acres or less), which was not nearly enough to support a family. Former slaves could be re-enslaved as well. In Elsinboro a census taker noted in 1797: "Bob Ludas and wife, he is servant owing to his fondness for rum." While advocating for the end of slavery, very few West Jerseyeans pushed for the end of racism and many held abolitionists held strong racist beliefs. Barzillia Jefferies wrote, "[slaves are] Generally when employed are pretty good to labour, but

\footnotetext{
${ }^{30}$ Several authors have discussed the notion of "free soil", but none recognize the region of West Jersey as one these spaces, nor do they recognize how early West Jersey became a "free soil" region. See, Seymour Drescher, Abolition: A History of Slavery and Antislavery (New York, 2009), 244-245. For a more robust discussion of "free soil" see Free Soil in the Atlantic World, Special Issue, Slavery and Abolition 32, no. 3 (September, 2011), especially Richard S. Newman, 'Lucky to be born in Pennsylvania': Free Soil, Fugitive Slaves and the Making of Pennsylvania's Anti-Slavery Borderland, in Free Soil in the Atlantic World, Special Issue, Slavery and Abolition 32, no. 3 (September, 2011), 413-430.
} 
subject to weaknesses and failures, too much prevailing to those of their colour." Andrew Congelton stated, "I may say that few of them labor further than necessity drive. Their morals I cannot say much in favor of some few of them seen to have a turn for religion, but the greater part seem rather loose and immoral." With dim economic prospects and with a powerful current of racism working against them, former slaves did as best as they could just to get by. ${ }^{31}$

Regardless of location, the slave community was always in flux. Slave families were often broken up after the death of a master. As runaway slave ads indicate, slave masters sold their slaves when their economic situation deteriorated. In some instances, slave owners relocated with their slaves to the expanding frontier. Slaves took advantage of the little freedoms they did gain during the twenty years following the American Revolution, by starting families, protecting their interests, and creating stronger communities. Between 1784 and 1804, even as the number of slaves increased in some parts of the state, the foundation of slavery seemed to be crumbling. With the adoption of the Gradual Abolition Bill (1804), slavery finally began to decline in East Jersey. It was the last Northern region to experience a decline in slavery, ushering in an end to a unique and sad chapter of New Jersey history.

\footnotetext{
${ }^{31}$ In 1798, the NJAS created a census of slaves and free blacks in West Jersey (save Cape May). The census takers took note of their numbers, names, property, and "moral conduct." The census is scattered in several archives. See Allinson Family Papers (1702-1949), Haverford College Special Collection, Haverford, Pa; New Jersey Abolition Society Papers, Burlington County Historical Society, Burlington, NJ.
} 
